\title{
頝喵道損傷者の社会生活とその問題点
}

〜患者追跡調査より〜

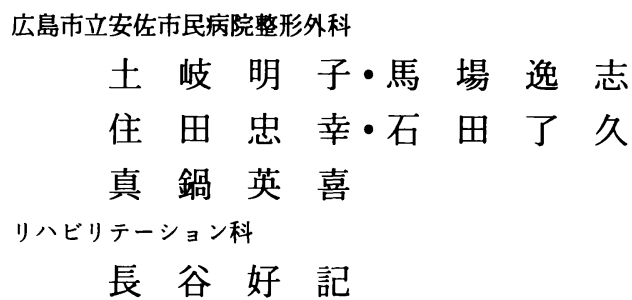

\section{Social Lives of Persons with Cervical Cord Injury}

\author{
Akiko Toki, Itsushi Baba, Tadayoshi Sumida, \\ Akihisa Ishida and Hideki Manabe \\ Department of Orthopaedic Surgery, Asa City Hospital of Hiroshima \\ Yoshiki Hase \\ Department of Rehabilitation, Asa City Hospital of Hiroshima
}

\begin{abstract}
It is difficult for persons with cervical cord injury (CCI) to live at home, because the increase in the number of nuclear families and families consisting only of old persons have led to a shortage of care given in a family. We followed up 42 persons with CCI injuries from January, 1987 to December, 1996, and evaluated their activities of daily living by the Modified Barthel Index (B.I.) score. There were 26 persons with less than 80 points on the B.I. 16 (61.5\%) lived at home and the others were in hospitals or facilities for the disabled. To maintain a proper life at home, they need to remodel their house, at least a care giver in their families, and social resources which support home care.
\end{abstract}

Key words : Cervical cord injury (頝髄損傷), Residence at home (自宅生活), House remodeling (家屋改造), Care giver（介護者)，Community resource（社会資源）

はじめに

高齢者世帯, 核家族の増加により家庭内の介護力が 低下してきているため，四肢麻瘒などの重度障害を負 う頝髄損傷者が自宅で生活するのは困難になってきて いると思われる. 今回私達は重度䅡髄損傷者について 追跡調查を行い，特に要介護状態で自宅生活を送って いるものについて住居の状況, 介護力に焦点を当て調 查した.

\section{対象および方法}

対象は 1987 年 1 月から 1996 年 12 月までに交通事 故や転落などの外傷により頚髅損傷受傷し, 受傷後 2 週間以内に当院入院したものである. 入院時 Frankel 分類で $\mathrm{A} \sim \mathrm{C}$ の実用歩行不可能であった 42 名にカル テ, 電話, 自宅訪問により, 追跡調查を行った. 受傷 時年齢は 6 歳から 85 歳, 平均 53.2 歳, 入院時 Frankel 分類は完全損傷の A 15 名, 不全損傷 B 4 名, 
実用歩行不可の C 23 名であった.

結果

1. 入院時 Frankel 分類と調查時 Barthel index $(\mathrm{BI})^{274)}$ の比較 (図 1)

入院時 Frankel 分類 $A$ の人は 15 名全員が全介助状 態にあった. 入院時 Frankel 分類 B, C の人は不自 由ながらむ $59.3 \%$ が BI が 81 点以上で介護が不要であっ た. 入院時の Frankel 分類が重度のものほど予後不 良であった。 B，Cの人で要介護状態にある人は 69 歳の一人を除いてすべて 75 歳以上の人で高齢者ほど 予後不良であった。

2. 現在の生活の場と Barthel index の関係（図 2)

$\mathrm{BI}$ が 81 点以上の日常生活動作がほぼ自立している 人は $81.3 \%$ 自宅に帰っていた. 残りは授産所や施設 であった. BI が 80 点以下の要介護状態の人では, 自 宅生活を送っているものが $61.5 \%$ と施設入所, 病院入 院中の人より多かった。

3. Barthel index が 80 点以下の自宅生活者の住 宅状況, 介護状況, サービスの利用状況

住宅状况 : 自宅を新築した人は 5 名,一部改造した 人は 7 名, 改造なしは 4 名であった. $75 \%$ の人が何ら かの改造をしていた。

介護状況 : 常時介護者（ほとんど常に在宅しており, 実際に介護を行っている人）が家族内に何人いるかを 調べた.「1人」の人が 13 名,「 2 人」が 1 名,「なし」 が 1 名,「必要なし」が 1 名であった。「1人」の 13

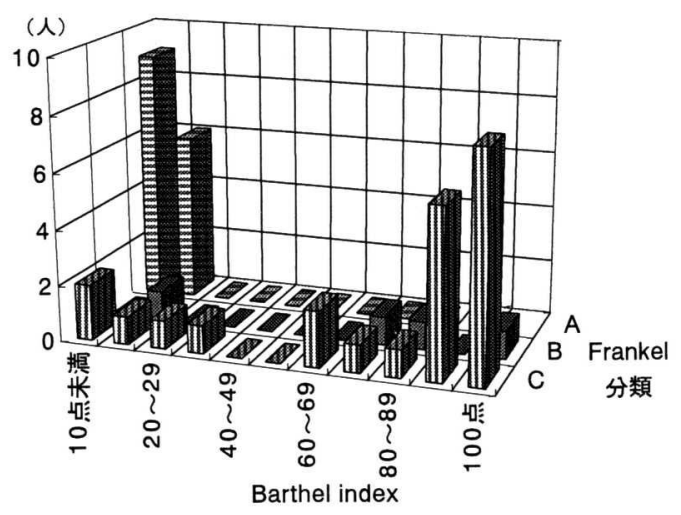

図 1 現在の日常生活レベル

入院時 Frankel 分類 Aの人は 15 名全員全介助状態に あった.
名のうち主たる介護者が配偶者である人は 11 名であっ た。「必要なし」の 1 名は専門機関にてリハビリテー ションをうけ，住居を新築することでほとんどの日常 生活動作が自立した症例である。「介護者なし」の 1 名は早朝, 夜間は夫が介護を行い, 日中は午前, 午後 之訪問看護, リハビリ，ヘルパーなどの社会サービス を一日に複数回受けていた.

サービスの利用状況 : 介護者の負担を軽滅させる社 会サービスには，自宅でサービスを受ける訪問看護サ一 ビス, 訪問リハビリ, 訪問ヘルパーなどと, 利用者が 出かけていくデイサービス・デイケアなどがある。一 般的に訪問看護サービス, 訪問リハビリの 1 回利用時 間は 1 時間, 訪問へルパーは 2 時間, デイサービス・ デイケアは 6 時間である.これに 1 週間当たりの平均 利用回数をかけ，延へ時間を比較した（図 3 )。16 世 帯中 12 世帯 $75 \%$ がいずれかのサービスを利用してお り, 利用回数は週 1 回から 10 回, 平均 3.9 回であっ た. よく利用されているサービスはデイサービス・デ イケア, 訪問看護, ヘルパーで, 利用時間が長く, 介 護負担を軽減する効果の高いものであった。

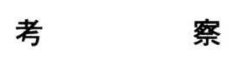

頝髄損傷者が家庭で生活する上での問題点として ADL が自立しておらず介護必要度が高いこと ${ }^{1 / 5) 6)}$, 家庭内の介護力が低いことが挙げられる。この対策と して, 頚䯣損傷者自身に対して入院中に十分なリハビ リを行い，ADLを最大限拡大することと，本人の自 立度を高め介護のしやすさに配慮した住宅の改造, 福

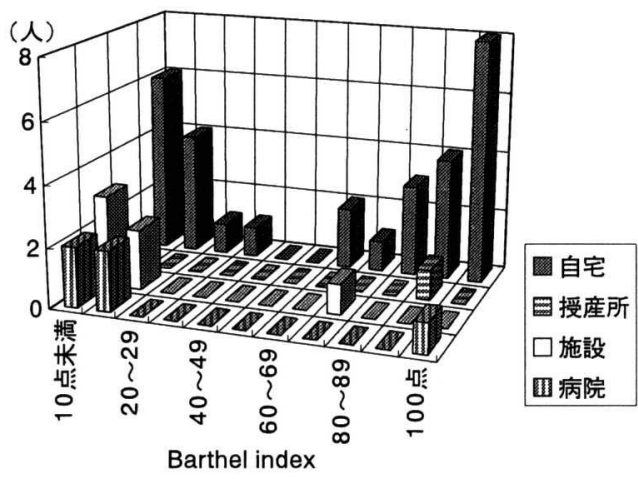

図 2 現在の Barthel index と生活の場 Barthel index が 80 点以下の要介護状態の人では, 自宅生活を送っているすのが $61.5 \%$ と施設入所, 病院入院中の人より多かった。 


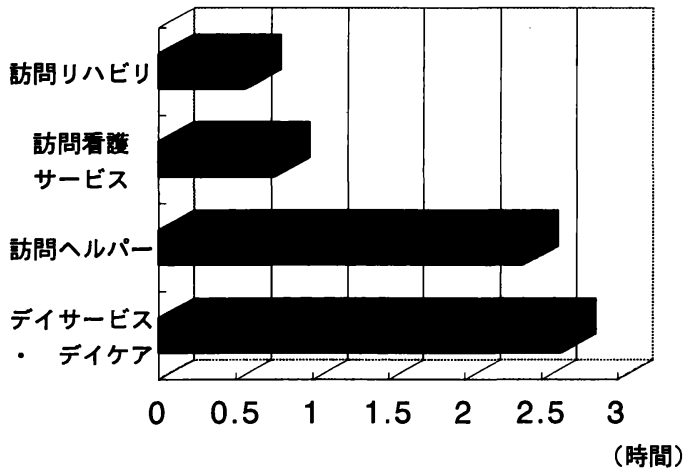

図 3 社会サービスの利用状况

1 回利用時間を訪問リハビリ，訪問看護サービスは 1 時間, 訪問ヘルパーは 2 時間, デイサービス・デイケ アは 6 時間とし，これに 1 週間当たりの平均利用回数 をかけ, 比較した。

祉機器の利用がある. また, 家庭内の介護力を補うも のとして, 夜間, 休日の訪問サービスや訪問の時間や 回数を増やすなどの社会サービスの充実, いざという ときの短期入所施設の確保などがあげられる.

頚䯣損傷者の自宅退院を可能にする社会環境として 川村ら ${ }^{3)}$ は, 1 ) 本人の ADL の拡大と介護のしやす さに配虑した住居，2）安定した介護力を得られるこ と，3）生活を支えることのできる経済基盤の 3 点を 挙げている. 今回の私達の調査であ自宅生活を送って いる人の $75 \%$ が住居を改造し, $87.5 \%$ が 1 人以上の常 時介護者を持ち， $75 \%$ がヘルパーなどの社会サービス
を補助的介護力として利用しており同様の結果であっ た. 頚髄損傷者が在宅で生活するためには住居の整備 と介護力の確保が重要と思われた.

結語

1. 頚㖪損傷者の退院後の実態調查を行った．要介 護状態の人の $61.5 \%$ が自宅で生活していた.

2. 自宅生活を可能にする条件は, 住環境の整備と 1 人以上の介護者を確保することであった.

3. 核家族, 高齢者世帯が多く, 家庭内の介護力の 低下が問題であった. 頝䯣損傷者の ADL を拡大し, 利用者のニーズに合わせて対応できるきめ細かいサー ビスの充実が望まれる.

\section{参考 文 献}

1）長谷川良雄ほか：高齢脊䯑道損傷者における社会問題. 総合リ八 $18: 439-443,1990$.

2）鎌倉矩子：ADL 能力障害. 総合リ八 $24: 939$ - 948, 1996.

3）川村次郎ほか：頸䯣損傷の自宅生活を可能とする社会 環境. 臨床リ八 $3: 568-573,1994$.

4）西村尚志 : ADL 評価の重要性. 臨床リ八 $5: 11-18$, 1996.

5）日本リハビリテーション医学会：2，脊䯣損傷のリハ ビリテーション. リハビリテーション白書, 第 2 版, 医 歯薬出版株式会社, 265-278, 1994.

6）松井和子 : 高位頸䯣損傷者の社会復㷌目標について. 日本パラプレジア医学会雑誌 $1: 110-111,1988$. 